\title{
CHAPTER FORTY-NINE
}

\section{EARLY MODERN PHILOSOPHICAL SYSTEMS}

\author{
Wiep van Bunge
}

The occurrence of an entry on early modern philosophical systems in an encyclopaedia of Neo-Latin studies is fraught with complications, if only on account of the gradual disappearance during the early modern period of Latin as the main vehicle of philosophical communication. What is more, historians of philosophy find it difficult to agree on exactly which period should count as 'early modern', and finally, experts on the period involved have raised serious doubts concerning the suitability of the notion of a 'system' in the historiography of philosophy in the period under review.

\section{The Use OF LATIN}

As far as the use of Latin is concerned, the majority of early modern philosophers still regarded as important were never employed as university professors: Giordano Bruno (1548-160o) was essentially a defrocked monk, his contemporary Francis Bacon (1561-1626) a lawyer and a politician, and René Descartes (1596-1650) a (minor) nobleman of independent means, while Thomas Hobbes (1588-1679) served as tutor and secretary to the Cavendish family. Benedictus de Spinoza (1632-1677) was an optician who even refused a chair offered to him by the University of Heidelberg, John Locke (1632-1704) was a physician, Gottfried Wilhelm Leibniz (1646-1716) was a diplomat and a librarian, George Berkeley (1685-1753) was a bishop, and so on. As a consequence, they were no longer bound by the conventions ruling academic scholarship, the main one being, of course, the use of Latin.
Admittedly, Bruno, Bacon, Descartes, Hobbes, and Spinoza still used Latin-Spinoza even exclusively so, the single text of his that has survived in Dutch, the Korte Verhandeling (c. 1660), being a translation made by his Amsterdam friends. ${ }^{1}$ To his considerable chagrin, Locke was quickly identified as the author of the anonymous Epistola de tolerantia, published in Gouda in 1689. Leibniz and Isaac Newton (1642-1727) also wrote much of their work in Latin, as did Immanuel Kant (1724-1804) for that matter, for not only were Kant's so-called pre-critical works composed in Latin, but from 1796 to 1798 Friedrich Gottlob Born (1743-1807) issued a translation of Kant's German works in four volumes, entitled Opera ad philosophiam criticam (1796-1798). In some cases the success a philosophical work enjoyed was solely due to its Latin translation: Tommaso Campanella's (1568-1639) La Città del sole (1602) was largely ignored until the author himself produced a version in Latin (1623). ${ }^{2}$ When Descartes met Isaac Beeckman (1588-1637) at Breda in 1619, the future author of the Discours de la méthode (1637) was able to communicate with Beeckman only because both men spoke Latin. ${ }^{3}$ But also among the so-called minor authors of the age, dozens could be named who still published many of their most important works in Latin,

1 Benedictus de Spinoza, Korte Verhandeling van God, de Mensch, en deszelvs Welstand, ed. by Filippo Mignini (L'Aquila: Japadre, 1986), pp. 71-80.

2 Françoise Waquet, Latin, or the Empire of a Sign from the Sixteenth to the Twentieth Centuries, transl. by James Howe (London and New York: Verso, 1998), p. 87.

3 Ibid., p. 154. 
including Marin Mersenne (1588-1648), Pierre Gassendi (1592-1655), Nicholas Malebranche (1638-1715), John Toland (1670-1722), Samuel Pufendorf (1632-1694), Christian Thomasius (1655-1728), and Christian Wolff (1679-1754). On the other hand, not all seventeenth- and eighteenth-century university professors felt obliged to publish exclusively in Latin: Galileo Galilei (1564-1642), Antoine Arnauld (16121694), Henry More (1614-1687), and Ralph Cudworth (1617-1688) all held important academic positions (although More, a Cambridge fellow, never made it to a professorial chair, he did become prebend), and they all published primarily in their native languages, as did, of course, such major political thinkers as Niccolò Machiavelli (1469-1527), Locke, and Charles Louis de Montesquieu (1689-1755).

Despite our increased awareness of the continuities between the 'old' and 'new' philosophies in the early modern age, and despite the evident connections between 'lay' philosophers opting for the vernacular and professional academics communicating exclusively in Latin, this did not alter the fact that Latin was a dead language, and could only be resuscitated at the expense of its purity. Moreover, the seventeenth century in particular witnessed a profound shift in paradigm: in natural philosophy as well as in metaphysics, from cosmography to the definition of matter and the explanation of change and motion, there is simply a world of difference between, say, the Cambridge Platonists and their contemporary John Locke, and not the least of these changes directly concerns their appreciation of the vernacular. Whereas More and Cudworth were still inspired by the vision of an 'Ancient Wisdom', an essentially timeless prisca sapientia, by contrast Locke's conception of philosophy as the task of what he called 'an Underlabourer' is completely oriented toward the future elucidation of issues concerning the theory of knowledge. A decisive blow to Latin's predominance was delivered with the publication in October 1696 of Pierre Bayle's (1647-1706) Dictionnaire historique et critique, since it corroborated the loss of faith the Republic of Letters had once bestowed on Latin: from now on, even the érudits were aban- doning the use of Latin. As a consequence, this entry will deal very little with the eighteenth century, when Latin had lost most of its relevance to the wider history of philosophy.

Most experts would agree that when natural philosophy, which during the sixteenth and seventeenth centuries had still served as the major arena in which the great battle between old and new conceptions of philosophy had been raging, grew into natural science, epistemology became the chief concern of philosophy, and accordingly it remained closely associated with the latest developments in physics in particular. Thus, once mechanicism took hold, the relevance of classical philosophy gradually evaporated, as did the use of Latin. As Peter Burke has pointed out, of the more than five hundred early modern translations from the vernacular into Latin that he has identified, a mere eighteen titles belong to philosophy. ${ }^{4}$ By the middle of the eighteenth century, in his Discours préliminaire to the Encyclopédie, Jean le Rond d'Alembert (1717-1783) observed the gradual decline of Latin and 'l'usage de toute écrire aujourdhui en langue vulgaire'. While d'Alembert acknowledged the advantages of this for French philosophes, he was also wary of where this might lead, for today, he continued, even Englishmen write in their native language, and even in Germany Latin is losing ground. Soon 'Swedes, Danes and Russians' will opt for the vernacular, he mused, and future scientists will have to master 'seven or eight' different languages before they will be able to pursue science. This would make the return of Latin highly desirable, d'Alembert mused. ${ }^{5}$ Latin did not return, of course, and d'Alembert knew full well that it would not.

4 Peter Burke, 'Translation into Latin in Early Modern Europe', in Cultural Translations in Early Modern Europe, ed. by Peter Burke and Ronnie-Po-chia Hsia (Cambridge: Cambridge University Press, 2007), pp. 65-80. See also Leonard W. Grant, 'European Vernacular Works in Latin Translation', Studies in the Renaissance, 1 (1954), 12-156.

${ }^{5}$ Jean Le Rond d'Alembert, Discours préliminaire, in Encyclopédie ou Dictionnaire raisonné des sciences, des arts et des métiers, 2 vols. (Paris: Flammarion, 1986), pp. $153^{-154}$. 


\section{'EARLY MODERN’ PHILOSOPHY}

Meanwhile, there is little agreement among the experts about which period in the history of philosophy should count as 'early modern'. Several major English series on the history of philosophy do not use the term: both Oxford and Cambridge University Presses issue series in which the seventeenth and eighteenth centuries are dealt with after a volume on 'the Renaissance'. ${ }^{6}$ As far as the relevant dates are concerned, Steven Nadler as editor of Blackwell's A Companion to Early Modern Philosophy starts with Bacon and Descartes and ends just before Kant. Donald Rutherford's The Cambridge Companion to Early Modern Philosophy follows this example closely. The five volumes which have so far appeared in the Oxford Studies in Early Modern Philosophy are also essentially a collection of papers 'from Descartes to Hume'. ${ }^{7}$ Knud Haakonssen, on the other hand, definitely includes the sixteenth century in his conception of early modern philosophy, and several contributors to Nadler's and Rutherford's volumes also tend to include the late Renaissance as well as the Reformation, insisting as they do on the continuity of 'early modern' thought. ${ }^{8}$

In particular, the flowering of sixteenthcentury Aristotelianism as well as the widespread recognition of its importance to the subsequent breakthrough of both the modern experimental approach to nature advocated by Bacon and the mathematical analysis of matter in motion advocated by Descartes, would seem to suggest that the century in which Bacon, Galileo, Gassendi, Hobbes, and Descartes were

${ }^{6}$ Charles B. Schmitt and Quentin Skinner (eds.), The Cambridge History of Renaissance Philosophy (Cambridge: Cambridge University Press, 1988); Brian P. Copenhaver and Charles B. Schmitt, Renaissance Philosophy (Oxford: Oxford University Press, 1993).

7 Edited by Garber and Nadler. Edwin Curley published a paper on Montaigne in the second volume only.

8 Knud Haakonssen, "The Idea of Early Modern Philosophy', in Teaching New Histories of Philosophy, ed. by J. B. Schneewind (Princeton, NJ: University Center for Human Values, 2004), pp. 99-121. See also his 'The History of Eighteenth-Century Philosophy: History or Philosophy?', in The Cambridge History of Eighteenth-Century Philosophy, 2 vols., ed. by Knud Haakonssen (Cambridge: Cambridge University Press, 2006), pp. 3-25. born should definitely be considered part of the early modern age in philosophy. In addition, it appears that a growing number of experts are prepared to regard the rise of (Neo-)Platonism during the Renaissance as an integral part of early modern philosophy as well. ${ }^{9}$ Thus, the historiography of philosophy has started to emulate the example set by cultural historians. Jonathan Dewald's recent six-volume Encyclopedia of the Early Modern World starts in 1450, while The Routledge Companion to Early Modern Europe begins in 1453. By extension, this would lead to the inclusion of, most notably, Marsilio Ficino's (1433-1499) recovery of Platonism as well as Hermeticism, although it would still exclude major critics of scholasticism, such as Lorenzo Valla $(c .1407-1457) \cdot{ }^{10}$ It might appear that the concept of early modernity including the Reformation is cherished most of all by scholars working in such predominantly Protestant countries as the United States and England, as well as Germany and the Netherlands. French historians do not have an equivalent to 'die frühe Neuzeit' as it was developed by Peter Burke and Heinz Schilling, to name just two of the more obvious pioneers in this respect, but they are accustomed to a similar distinction between 'l'époque contemporaine' and 'l'époque moderne', which, however, is also referred to as 'l'Ancien Régime'. When it is, the term usually includes the latter stages of the Renaissance as well as the discovery of the Americas at the end of the fifteenth century, or, to put it differently, it starts well before the ascension of the Bourbon dynasty in $1589 .{ }^{11}$

The view propounded by Nadler and Rutherford, that there is a crucial difference in the history of philosophy between the sixteenth and seventeenth centuries, has a long and

9 See, for instance, Michael Ayers (ed.), Rationalism, Platonism and God (Oxford: Oxford University Press, 2007), and Douglas Hadley and Sarah Hutton (eds.), Platonism at the Origins of Modernity (Dordrecht: Springer, 2008).

10 Lodi Nauta, In Defense of Common Sense. Lorenzo Valla's Humanist Critique of Scholastic Philosophy (Cambridge, MA: Harvard University Press, 2009).

11 Notable examples are François Bluche and Robert Muchembled. 
distinguished pedigree. Self-proclaimed 'novatores', such as Bacon and Descartes, went out of their way to emphasise the revolutionary nature of their own intervention, and the willingness of many other seventeenth-century philosophers to take sides in the debate between 'old' and 'new' philosophy seems to confirm the contemporary perception of a shift in paradigms. This sense of being part of a novel enterprise, which could only start by shaking off 'the yoke' of the old, appears to have been widespread among natural philosophers in particular. A telling illustration is supplied by Christiaan Huygens (1629-1695), a man who was not at all given to polemics and who remained distrustful of metaphysical speculation throughout his life. When in the 169os he was asked by Pierre Bayle to comment on the significance of Descartes's legacy, he replied that it had been Descartes's main achievement to silence the Aristotelians, that is, to get rid of a number of Peripatetic concepts no longer of use in the explanation of matter in motion. ${ }^{12}$ Very similar sentiments were expressed in Johann Jacob Brucker's (1696-1770) highly influential Historia critica philosophiae of 1742-1744, which shaped as well as reflected contemporary perceptions of the history of early modern thought. ${ }^{13}$

Haakonssen's inclusion of the sixteenth century, it should be added, rests upon a deeply felt concern over the notion of 'early modern philosophy' itself. According to Haakonssen, it suffers from the view, the rise of which he attributes to both Kant and Thomas Reid (17101796), according to which the theory of knowledge is the proper subject of philosophy as such. According to Haakonssen, the very concept of 'early modern philosophy' is essentially part of what he calls an 'epistemological paradigm'

12 Christiaan Huygens, Oeuvres complètes, ed. by D. Bierens de Haan, J. Bosscha, D. J. Korteweg, and J. A. Vollgraff, 22 vols. (The Hague: Martinus Nijhoff, 18881950), X, p. 403.

13 See, for instance, Constance Blackwell, 'Jacob Brucker's Theory of Knowledge and the History of Natural Philosophy', in Jacob Brucker (1696-177o). Philosoph und Historiker der europäischen Aufklärung, ed. by Wilhelm Schmidt-Biggemann and Theo Stammen (Berlin: Akademie Verlag, 1998), pp. 198-217. which fails to capture the contemporary selfassessment of early modern philosophy. ${ }^{14}$ Ethics, politics, and aesthetics have suffered most obviously from this, and more generally, Haakonssen continues, the narrowing of the moral dimension of pre-Kantian moral thought to its ability to justify moral propositions completely ignored the widely shared conviction that philosophy was to contribute to the shaping of the self, that it should first and foremost be lived. Most important, however, Haakonssen takes the epistemological paradigm to task over its 'individualism and mentalism - the assumption that knowledge has to be accounted for in terms of the activity (or passivity) of the individual person's mind', ${ }^{15}$ which obscures the fundamental debates on historical testimony as well as the non-mentalist aspects of much of the seventeenth- and eighteenth-century philosophy of language. As true and as important as Haakonssen's objections to the use of the concept of 'early modern philosophy' are, they are largely based on recent examinations of the period involved: apparently, presentday research into early modern philosophy has become acutely conscious of both the philosophical and the historical pitfalls into which any uncritical use of the concept can lead us. ${ }^{16}$

\section{Philosophical 'SYstems'}

A third, crucial objection to the use of 'early modern system' in philosophy has recently been voiced by Leo Catana, the Danish author of an incisive monograph on the virtues of the

14 Haakonssen, 'The Idea of Early Modern Philosophy', pp. 103-104.

15 Ibid., p. 114.

16 It will come as no surprise that Haakonssen, the celebrated author of Natural Law and Moral Philosophy. From Grotius to the Scottish Enlightenment (Cambridge: Cambridge University Press, 2006), is especially appreciative of T. J. Hochstrasser, Natural Law Theories in the Early Enlightenment (Cambridge: Cambridge University Press, 2000) and Ian Hunter, Rival Enlightenments. Civil and Metaphysical Philosophy in Early Modern Germany (Cambridge: Cambridge University Press, 2001). 
historiographical concept 'system of philosophy'. ${ }^{17}$ Focussing on the pivotal role played by Brucker's mid-eighteenth-century Historia critica philosophiae, Catana clearly demonstrates the extent to which in particular Brucker's conception of a philosophical system impregnated the subsequent rise of the discipline of history of philosophy. As it turns out, Brucker's periodisation of what we have come to regard as early modern philosophy was largely derived from Christoph August Heumann's (1681-1764) 'Eintheilung der historiae philosophicae', a long article published in the first issue (1715) of the Acta philosophorumarguably the first ever journal of philosophy, edited by Heumann himself. ${ }^{18}$ Heumann's main aim appears to have been to distinguish a properly philosophical understanding of the history of philosophy from the essentially philological approach which had dominated seventeenth-century discussions on the subject. Heumann, a Lutheran pastor by training, felt that the historian had to be in a position to pass judgement on the doctrines presented, and following this highly normative lead, he felt that 'a new philosophical world' had emerged only with the Reformation, which had liberated the individual from undue reverence to authority in general. Brucker's understanding of the development of philosophy since the Reformation followed Heumann's in, for instance, the latter's insistence on the apparent similarity of theology and philosophy in the opposition they saw between sectarianism and eclecticism; only eclecticism, or so they both argued, could result in the construction of a 'system', whereas sectarians lack the libertas philosophandi necessary for this essentially critical task.

For all intents and purposes, the conception of the history of philosophy that Brucker inherited from Heumann was part of a polemical effort aimed at demonstrating the intellectual inferiority of Aristotelian 'sectarianism', and Catana has clearly demonstrated the

17 Leo Catana, The Historiographical Concept 'System of Philosophy'. Its Origin, Nature, Influence and Legitimacy (Leiden and Boston: Brill, 2008).

18 Ibid., ch. 5 . extent to which, for instance, Giordano Bruno's work was misrepresented by Brucker's and Heumann's shared insistence on 'systematic' thought. ${ }^{19}$ Compelling as Catana's rejection of the demand for systematic philosophy may be, during the entire seventeenth century less strenuous definitions of 'system' than Brucker's deductive one were widespread. As a rule, 'systema' referred to little more than an orderly exposition, mainly used for pedagogical purposes. ${ }^{20}$ During the early 1600 , Bartholomeus Keckermann (1573-1609) published a series of systemata, including a Systema logicae (1607), a Systema scientiae metaphysicae (1609), and a Systema ethicum (1610), as well as physicum (1612). His former student Clemens Timpler (1563-1624) published both a Philosophia seu philosophiae naturalis systema (1609-1613) and a Philosophiae practicae systema (1610-1612). As early as 1612 the Lutheran minister Constantin Cnirim (?-1627) published an Isagogicum primae philosophiae systema (1612), and the polyhistor Georg Andreas Fabricius (1589-1645) composed a Thesaurus philosophicus sive tabulae totius philosophiae systema (1624). The Jena professor of practical philosophy Wolfgang Heider (1558-1626) published a Philosophiae politicae systema (1628), and in 1658 the Tübingen professor of logic and metaphysics Johann Grafft (1618-1695) issued a Systema philosophiae naturalis.

The term, systema, moreover, was not confined to didactic eclecticism. Following the ancient, predominantly Stoic concept of 'systema mundi' as referring to cosmography and astronomy, both Galileo's and Newton's most famous works concerned 'World Systems', and even Isaac la Peyrère's (1596-1676) infamous hypothesis regarding the 'pre-adamites' was put forward in a Systema theologicum (1655). Indeed, the use of the term during the seventeenth century in particular appears virtually

19 Ibid., ch. 2 and 4.

20 Cf. Amos Funkenstein, Theology and the Scientific Imagination from the Middle Ages to the Seventeenth Century (Princeton, NJ: Princeton University Press, 1986), p. 6, n. 9, where 'system' is defined as no more than 'an edifice of integrated propositions'. 
ubiquitous, and it would seem that it did indeed result mainly from the very eclecticism that served as Brucker's point of departure. According to Brucker, the history of philosophy consisted of three periods: after the first period of 'barbaric', that is, pre-Christian, philosophy, and the second one, which began with the rise of the Roman Empire and ended with the 'crisis' of scholasticism, a third period started in the early fourteenth century with the recovery of ancient sources. After an initial phase characterised by syncretism from the fifteenth century onwards, eclecticism held sway, Brucker said, and this was all for the better. ${ }^{21}$ As it happens, early modern eclecticism has recently gone through a considerable reappraisal, and it is surely no coincidence that it was first recovered by research into the early modern historiography of philosophy. ${ }^{22}$ For one thing, it appears to have been widespread, particularly at the German and Dutch universities of the time. Yet it is far from obvious that it engendered 'systematic' thought. Its main ambition was to argue in favour of 'libertas philosophandi', and as a rule it took on the shape of a 'philosophia novantiqua', a philosophy made up of 'old' and 'new'. Thus it sought to make room for innovation within the boundaries of received tradition.

\section{Philosophia VETUS}

During the entire early modern period Aristotelianism remained the most important school of thought descended from Antiquity, and it owed

21 Catana, The Historiographical Concept, p. 24.

22 Giovanni Santinello and Constance T. Blackwell (eds.), Models of the History of Philosophy. Volume I: From Its Origins in the Renaissance to the Historia Philosophica (Dordrecht: Kluwer, 1993), and Gregorio Piaia and Giovanni Santinello (eds.), Models of the History of Philosophy. Volume II: From the Cartesian Age to Brucker (Dordrecht: Springer, 2011). See also Wilhelm Schmidt-Biggemann, Topica Universalis. Eine Modellgeschichte humanistischer und barocker Wissenschaft (Hamburg: Felix Meiner, 1983); Michael Albrecht, Eklektik. Eine Begriffsgeschichte mit Hinweisen aufdie Philosophie und Wissenschaftsgeschichte (Stuttgart: Frommann Holzboog, 1994); Donald R. Kelley, 'Eclecticism and the History of Ideas', Journal of the History of Ideas, 62 (2001), 577-592. For the many examples drawn from the Dutch context, see Paul Dibon, Regards sur la Hollande du siècle d'Or (Naples: Vivarium, 1990). its prominence to the way in which from the thirteenth century onwards it had been institutionalised in the academic infrastructure covering Western Europe. ${ }^{23}$ This is evident, for instance, from the academic textbooks produced from the early 1500 on onwards in particular, which were overwhelmingly Aristotelian. ${ }^{24}$ The huge advantage of Peripateticism was, of course, the suitability of its textual basis for the academic curriculum. Especially the philosophical courses to be delivered in the propaedeutic faculties of arts were habitually based on the Corpus Aristotelicum. What is more, from the fourteenth to the seventeenth centuries many hundreds of commentaries were written on Aristotle. The rediscovery over the past few decades of the vitality of early modern Peripateticism was made possible first by a fundamental re-evaluation of the role of the universities in the history of science. Although it remains true that early modern universities served mainly as institutions of education, it is equally clear that the large majority of the early members of such research institutes as the Royal Society and the Académie Royale des Sciences

23 Charles B. Schmitt, Aristotle and the Renaissance (Cambridge, MA: Harvard University Press, 1983); Christa Mercer, 'The Vitality and Importance of Early Modern Aristotelianism', in The Rise of Modern Philosophy. The Tension between the New and Traditional Philosophies from Machiavelli to Leibniz, ed. by Tom Sorell (Oxford: Clarendon Press, 1993), pp. 33-67; Daniel A. Di Liscia, Eckhard Kessler, and Charlotte Methuen (eds.), Method and Order in Renaissance Philosophy of Nature. The Aristotle Commentary Tradition (Aldershot: Ashgate, 1997); Constance Blackwell and Sachiko Kusukawa (eds.), Philosophy in the Sixteenth and Seventeenth Centuries. Conversations with Aristotle (Aldershot: Ashgate, 1999); Eckhard Kessler, Charles H. Lohr, and Walther Sparn (eds.), Aristotelismus und Renaissance. In Memoriam Charles B. Schmitt (Wiesbaden:Harrassowitz, 1988); Roger Ariew and Alan Gabbey, 'The Scholastic Background', in The Cambridge History of Seventeenth-Century Philosophy, 2 vols., ed. by Daniel Garber and Michael Ayers (Cambridge: Cambridge University Press, 1998), pp. 425-453; Cees Leijenhorst, Christoph Lüthy, and Johannes H. H. M. Thijssen (eds.), The Dynamics of Aristotelian Natural Philosophy from Antiquity to the Seventeenth Century (Leiden and Boston: Brill, 2002); Ricardo Pozzo (ed.), The Impact of Aristotelianism on Modern Philosophy (Washington, DC: The Catholic University of America Press, 2004).

24 Charles B. Schmitt, 'The Rise of the Philosophical Textbook', in Schmitt and Skinner (eds.), The Cambridge History of Renaissance Philosophy, pp. 792-804. 
shared an academic background. In 1592 Galileo took the chair at Padua that Bruno had coveted. ${ }^{25}$ To this day, Cambridge prides itself on having had Newton as a professor of mathematics. Several universities, such as Padua and Leiden in particular, fostered research traditions of their own that were closely associated with the teaching of (natural) philosophy and medicine. ${ }^{26}$ Mordechai Feingold has called attention to the crucial work on mathematics done at Oxford and Cambridge well before Newton. ${ }^{27}$

A second obstacle to be overcome before the importance of early modern Aristotelianism was to be properly understood concerned the recognition of its intellectual diversity. Just before his untimely death in 1986, Charles B. Schmitt famously summed up his definitive view on the matter, pointing out that Renaissance Aristotelianism basically consisted of eight different varieties, ranging, amongst others, from the early fifteenth-century Romanising of Aristotle's political views by Leonardo Bruni (c. 1370-1444) and the late fifteenthcentury efforts by Jacques Lefèvre d'Étaples (c. 1455-1536) to cleanse Aristotle's logical writings of mediaeval 'barbarisms', to the views of the early sixteenth-century Paduan scientist Pietro Pomponazzi (1462-1525), who turned to the Stagirite as a natural philosopher and a psychologist. ${ }^{28}$ Both Pomponazzi's search for nat-

25 William A. Wallace, Galileo's Sources. The Heritage of the Collegio Romano in Galileo's Science (Princeton, NJ: Princeton University Press, 1984); Edward Grant, The Foundations of Modern Science in the Middle Ages (Cambridge: Cambridge University Press, 1986).

26 John Gascoigne, 'A Reappraisal of the Role of the Universities in the Scientific Revolution', in Reappraisals of the Scientific Revolution, ed. by David C. Lindberg and Robert S. Westman (Cambridge: Cambridge University Press, 1990), pp. 207-26o; Olaf Pedersen, 'Tradition and Innovation', in Universities in Early Modern Europe (1500-180o), ed. by Hilde de Ridder-Symoens (Cambridge: Cambridge University Press, 1996), pp. 451-488; Roy Porter, 'The Scientific Revolution and the Universities', in de Ridder-Symoens (ed.), Universities in Early Modern Europe (1500-180o), pp. 531-562.

27 Mordechai Feingold, The Mathematician's Apprenticeship. Science, Universities and Society in Britain, 15601640 (Cambridge: Cambridge University Press, 1984).

28 Copenhaver and Schmitt, Renaissance Philosophy, ch. 2. ural causes behind 'miracles' and his work on De anima resulted in his enduring reputation as a 'naturalist', an early freethinker, and even an 'atheist', while his main ambition merely appears to have been to separate philosophical enquiry from theological considerations. In particular his comments on the ambiguities involved in Aristotle's assessment of the personal immortality of the soul barely escaped censure. ${ }^{29}$

With the exception of the Mechanics and the Poetics, which became available only by the middle of the fifteenth century, the entire Corpus Aristotelicum now at our disposal was known in the Latin West as early as the end of the thirteenth century. What was added during the early modern age, however, was a growing preparedness to study Aristotle in Greek as well as a very important series of Greek commentaries, many of which were written by Platonists. This added in no small degree to the emergence of a wide variety of interpretations, as did the more general difference in orientation between Northern European and Italian Aristotelianism: whereas Parisian, German, and English Peripatetics concentrated on metaphysics and logic in their continuing attempt to put Aristotelianism to apologetical purposes, at Padua in particular a secular Aristotelianism arose, mainly directed towards the study of nature. As will be only too familiar, both Catholic and Protestant philosophers and theologians turned to the Stagirite looking for conceptual ammunition in the ongoing battle of the Reformation.

Whereas early modern Aristotelianism was the product of a score of scholars throughout Europe, the fifteenth-century renaissance of Platonism was very much the outcome of the efforts of a single man and his lifelong obsession to recapture the timeless truths of the 'prisca sapientia'. ${ }^{30}$ This man, Marsilio Ficino, was

29 Martin L. Pine, Pietro Pomponazzi. Radical Philosopher of the Italian Renaissance (Padua: Antenore, 1986); Jill Kraye, 'Pietro Pomponazzi (1462-1525). Secular Aristotelianism in the Renaissance', in Philosophers of the Renaissance, ed. by Paul Richard Blum (Washington, DC: The Catholic University of America Press, 2010), pp. 92-115.

30 Paul Oskar Kristeller, The Philosophy of Marsilio Ficino(Gloucester, MA: Peter Smith, 1964); James Hankins, 
employed in Florence by Grand Duke Cosimo de Medici (1389-1464) as his grandson Lorenzo's (1449-1492) tutor. It was Ficino's expertise in Greek which enabled him to produce the first complete Latin translation of Plato's dialogues, only some of which, including the Timaeus, Meno, and Phaedo, had been known in the West, and then only in part. This first edition of his Platonis opera omnia (1484) sold over a thousand copies, and it would remain the standard text for centuries to come. During the sixteenth century it would run to more than thirty editions. In 1499 a Greek edition followed, yet the very nature of the philosophical dialogue prevented Plato's works from acquiring any status as academic teaching material.

Despite his philological acumen, Ficino deliberately ignored such questions as the development of Plato's thought, its historical context, and the differences between the master and Neo-Platonists such as Proclus and Plotinus, whose work he also carefully edited and translated. Instead he was dedicated to the belief that Plato's works were essentially part of an ancient chain of wisdom that had originated in ancient Egypt and had previously inspired, for example, Moses as well as the Pythagoreans. ${ }^{31}$ In Ficino's eyes, the time had come to rekindle this 'prisca sapientia' or 'theologia', and once his patron in 1462 had purchased a complete copy of the so-called Corpus Hermeticum, Ficino was sure that he had discovered the original source of this ancient tradition. Nine years later his edition of this text, which he

Plato in the Italian Renaissance, 2 vols. (Leiden: Brill, 1991); Michael J. B. Allen, Valery Rees, and Martin Davies (eds.), Marsilio Ficino. His Theology, His Philosophy, His Legacy (Leiden and Boston: Brill, 2002); Christa Mercer, 'Platonism and Philosophical Humanism on the Continent', in A Companion to Early Modern Philosophy, ed. by Steven Nadler (Oxford: Blackwell, 2002), pp. 25-44; Christopher S. Celenza, 'The Revival of Platonic Philosophy', in The Cambridge Companion to Renaissance Philosophy, ed. by James Hankins (Cambridge: Cambridge University Press, 2007), pp. 72-96.

31 Frances Yates, Giordano Bruno and the Hermetic Tradition (London: Routledge and Kegan Paul, 1964); D. P. Walker, The Ancient Theology. Studies in ChristianPlatonism from the Fifteenth Century to the Eighteenth (London: Duckworth, 1974); Martin Mulsow, "The Ambiguities of the Prisca Sapientia in Late Renaissance Humanism', Journal of the History of Ideas, 65 (2004), 1-13. attributed to the legendary priest Hermes Trismegistus, appeared, by which time he had all but completed his own Theologia Platonica de immortalitate animae (1482) as well. Recently, an important new edition and complete translation into English has been published in the I Tatti Renaissance Library of Harvard University Press. ${ }^{32}$

Ficino's 'theology' revealed a strictly hierarchical picture of the world which exists between the One and the Good at one end, and Non-being and Evil at the other. The One and the Good transcend being in that they are a condition for being. Thus, the living universe, which is animated by a World Soul, exists on a scale of reality in the middle of which the human soul resides: it is capable of greatness, but it can also fall far. Here, Ficino clearly followed Proclus and Plotinus, rather than the dialectic of Plato's dialogues, and in doing so he was to inspire both Giordano Bruno and Francesco Patrizi (1529-1597). ${ }^{33}$ In view of the Neo-Platonist elements also pervading Nicholas of Cues's (1401-1464) work, ${ }^{34}$ no other conclusion seems warranted than that by the end of the sixteenth century the classical heritage in philosophy had been rejuvenated forcefully both in its Aristotelian and in its Platonist varieties. Isaac Casaubon's (1559-1614) discovery in the early seventeenth century-that in reality the Corpus Hermeticum was composed in the second or third century AD-would not affect the continuing presence of Platonism in early modern philosophy. ${ }^{35}$

32 Marsilio Ficino, Platonic Theology, 6 vols., ed. by James Hankins, transl. by Michael J. B. Allen (Cambridge, MA: Harvard University Press, 2001-2009).

33 Yates, Giordano Bruno and the Hermetic Tradition; Hilary Gatti, Giordano Bruno and Renaissance Science (Ithaca, NY: Cornell University Press, 1999); id., Essays on Giordano Bruno (Princeton, NJ: Princeton University Press, 2011). On Patrizi, see, for instance, Cees Leijenhorst, 'Francesco Patrizi's Hermetic Philosophy', in Gnosis and Hermeticism from Antiquity to the Modern World, ed. by Roelof van den Broek and Wouter J. Hanegraaff (Albany, NY: State University of New York Press, 1998), pp. 125-146.

34 See, for instance, Inigo Bocken (ed.), Conflict and Reconciliation. Perspectives on Nicholas of Cusa (Leiden and Boston: Brill, 2004).

35 Anthony Grafton, Defenders of the Text. The Traditions of Scholarship in the Age of Science, 1450-180o (Cambridge, MA: Harvard University Press, 1991), ch. 5 and 6. 
A third source of the revival of classical thought in the sixteenth and seventeenth centuries is to be found in the schools which blossomed in the Hellenistic age. Scepticism or 'Pyrrhonism' should be mentioned first on account of the impact its rediscovery has had on our understanding of the course of early modern philosophy. ${ }^{36}$ The very structure of the scholastic 'quaestio', demanding arguments 'pro et contra', could easily lead to scepticism, and in late scholasticism thought experiments concerning the consequences to be drawn from God's omnipotence had also led to serious questions about the human capacity to acquire indubitable knowledge. Yet the recovery of the textual material from Antiquity in which the main arguments developed by classical sceptics had been brought together added a completely new dimension to the issue of our ability to come to any reliable knowledge regarding the external world. No other author would have such an impact as Sextus Empiricus, whose Outlines of Pyrrhonism and Adversus mathematicos were both published in the 1560 os.

As has been argued with a singular tenacity by Richard H. Popkin, and subsequently further developed by a host of American and European scholars, the sudden availability to European men of letters of the complete armoury of classical 'Pyrrhonism' fit hand in glove with a series of cultural revolutions that, each in its own way, had the potential to serve as a cause for doubt. First, the recent rediscovery of many classical texts demonstrated the richness of classical, that is, pre-Christian, Antiquity, which made it increasingly difficult to uphold the obvi-

See also Martin Mulsow (ed.), Das Ende des Hermetismus (Tübingen: Mohr Siebeck, 2002).

36 Charles B. Schmitt, Cicero Scepticus. A Study of the Influence of the Academica in the Renaissance (The Hague: Martinus Nijhoff, 1972); Richard H. Popkin and Charles B. Schmitt (eds.), Scepticism from the Renaissance to the Enlightenment (Wiesbaden: Harrassowitz, 1987); Myles Burnyeat (ed.), The Skeptical Tradition (Berkeley: University of California Press, 1983); Richard H. Popkin, The History of Scepticism from Savonarola to Bayle (Oxford: Oxford University Press, 2003); Dominik Perler, Zweifel und Gewissheit. Skeptische Debatten im Mittelalter (Frankfurt a.M.: Vittorio Klostermann, 2006); Gianni Paganini and José R. Maia Neto (eds.), Renaissance Scepticisms (Dordrecht: Springer, 2010). ous superiority of Christian civilisation. This journey through time was supplemented with journeys of discovery through space: explorers came into contact with impressive and clearly long-standing civilisations that were literally on the other side of the globe, none of which, for obvious reasons, were Christian either. Next, the invention of printing accelerated the circulation of knowledge, and previously undreamt-of possibilities emerged for creating private libraries. During the sixteenth century, the wealth of information thus created became a source for doubt itself: the bewildering variety of classical philosophical schools of thought and the gradual recognition that, for instance, the peoples of the Americas were part of humanity increasingly presented European scholars with the possibility of broadening their perspective.

Add to this first the Reformation, which ended the unquestioned authority in Europe of a single Catholic Church, and second Nicolaus Copernicus's (1473-1543) De revolutionibus orbium (1543), which would gradually be recognised as the first step towards a heliocentric instead of a geocentric picture of the universe, and the impact Sextus Empiricus's catalogue of sceptical arguments had on its late sixteenthand seventeenth-century readers becomes easy to understand. There was every reason to question some of the most 'obvious' truths concerning the world, its inhabitants, and their cultures that European scholars had grown accustomed to. Traditionally, scepticism had served a long tradition of fideism: from the earliest encounters between Christian theologians and Greek philosophers, the frailty of human reason had been presented as a major argument in favour of faith. Although this line of reasoning was also strongly present in the work of Michel de Montaigne (1533-1592), who was the first major author to see the full potential of Sextus Empiricus's legacy, his three books of Essais (1580; first complete edition: 1595), and in particular his cultural relativism, were to have a lasting and potentially dangerous effect on the authority of revealed religion.

Montaigne's views were further elaborated by his close friend and former pupil Pierre Charron (1541-1603), whose De la sagesse (1601) 
would be violently attacked by Catholic polemicists, who argued that it contained covert atheism. It would, however, also become a major source of inspiration to a group of early seventeenth-century scholars who were mainly active in Paris and were collectively known as the 'libertinage érudit'. ${ }^{37}$ Like Montaigne and Charron, they also admired the moral philosophy of the Stoics. Unlike Montaigne and Charron, however, several 'libertins' preferred publishing in Latin rather than French, and their interest in classical philosophy included most notably Democritus's, Epicurus's, and especially Lucretius's atomism. This, of course, only added to the widespread suspicions concerning their religious orthodoxy, as did their interest in Machiavelli's and Giulio Cesare Vanini's (1585-1619) emphasis on the political function of revealed religion. By the end of the 1650 s an anonymous author, no doubt one with a libertine background, composed a very impressive so-called clandestine manuscript entitled Theophrastus redivivus, the first overtly atheist philosophical treatise written after the establishment of Christianity in Europe. ${ }^{38}$ On the basis of classical sources, but also quoting Pomponazzi, Machiavelli, Charron, Gabriel Naudé (1600-1653), and Guy Patin (1601-1672), the author argued against the existence of a providential deity, concluding that politically expedient as religions may be, they are essentially illusory. The recent rediscovery of the early modern genre of clandestine manuscripts has also brought to light the extent to which

37 René Pintard, Le Libertinage érudit dans la première moitié du XVII e siècle (Geneva: Slatkine, 2000 (1943)); Tulio Gregory, Etica e religione nella critica libertina (Naples: Bibliopolis, 1986); Françoise Charles-Daubert, Les libertins érudits en France au XVII siècle (Paris: Presses Universitaires de France, 1998); Jean-Pierre Cavaillé, Dissimulations. Religion, morale et politique au XVII siècle Jules-César Vanini, François La Mothe Le Vayer, Gabriel Naudé, Louis Machon et Torquato Accetto (Paris: Honoré Champion, 2002).

38 It was first published in the early 1980 s by Canziani and Paganini. See also Winfried Schröder, Ursprünge des Atheismus. Untersuchungen zur Metaphysik- und Religionskritik des 17. und 18. Jahrhunderts (Stuttgart and Bad Canstatt: Frommann-Holzboog, 1998), ch. 4. classical scepticism continued to inform some of the most advanced attacks on the claims of revealed religions, including such texts as the Symbolum sapientiae. ${ }^{39}$

Meanwhile, both Stoicism and Epicureanism were also starting to enjoy considerable success from the early seventeenth century onwards. Instrumental in the revival of the Stoa were Justus Lipsius's (1547-1606) efforts: a distinguished academic at Louvain and Leiden, in 1584 he published his De constantia, which became a bestseller. ${ }^{40}$ This reinvention of Stoic morality for the benefit of the individual facing calamities such as the fall of Antwerp, which was to take place the following year, would in 1589 be supplemented by a six-part treatise on the political philosophy of the Stoa, as well as by a Manuductio ad stoicam philosophiam and a Physiologia stoicorum, both published in 1604 . Lipisus's edition of Seneca (1605) completed his efforts to restore the Stoic tradition. All the while, Lipsius had taken considerable care to show that its pagan origins did not have to lead to any serious conflict with Christianity.

The revival of Epicureanism was to run up against much stronger opposition from both the Catholic and the Protestant churches. ${ }^{41}$ In

39 G. Canziani, W. Schröder, F. Socas (eds.), Cymbalum mundi sive Symbolum sapientiae. See, on this genre, in which Latin would continue to be used until well into the eighteenth century: Miguel Benítez, La face cachée des Lumières. Recherches sur les manuscrits philosophiques clandestins de l'âge classique (Paris and Oxford: Universitas-The Voltaire Foundation, 1996); Antony Mc Kenna and Alain Mothu (eds.), La philosophie clandestine à l'age classique (Paris and Oxford: Universitas-The Voltaire Foundation, 1997).

40 Jason Lewis Saunders, Justus Lipsius. The Philosophy of Renaissance Stoicism (New York: Liberal Arts Press, 1955); Gerhard Oestreich, Neostoicism and the Early Modern State (Cambridge: Cambridge University Press, 1982); Margaret J. Osler (ed.), Atoms, Pneuma and Tranquility. Epicurean and Stoic Themes in European Thought (Cambridge: Cambridge University Press, 1991); Jacqueline Lagrée, Juste Lipse et la restauration du stoïcisme. Etude et traduction des traités stö̈ciens De la constance, Manuel de philosophie stö̈cienne, Physique des stö̈ciens (Paris: Vrin, 1994).

41 Catherine Wilson, Epicureanism at the Origins of Modernity (Oxford: Oxford University Press, 2008); Alison Brown, The Return of Lucretius to Renaissance Florence (Cambridge, MA: Harvard University Press, 2010). 
particular, Lucretius's De rerum natura, first edited in 1495 , was widely considered to be a major threat to the authority of revealed religion. It was also admired, however, by Montaigne, Charron, and the 'libertinage érudit', and although its atheism fitted poorly with the theist worldview of such early members of the Royal Society as Robert Boyle (1627-1691), its atomism strongly appealed to British and French natural philosophers looking for corpuscular theories of matter. Thomas Hobbes was a great admirer, but in particular Pierre Gassendi's attempts to adapt the Epicureanism of Lucretius to Christian uses were appreciated in Britain, and may well have been seriously underestimated by historians of philosophy, as has recently been argued by Catherine Wilson.

\section{PHILOSOPHIA NOVA}

There is no major seventeenth-century philosopher who was not, in one way or another, deeply indebted to classical philosophy, yet by the end of the century the sense of direction of European philosophy had changed for good. Particularly after Descartes the direction of philosophy in general had altered: it was no longer preoccupied with the elucidation and analysis of authoritative texts, but rather with the conceptual exploration of the world, including the way in which man inhabited it from a mental, moral, and social point of view. Wisdom was no longer a virtue to be regained, but had rather become a quality to be fostered on the basis of a proper insight into man's natural constitution. And Descartes was crucial in the transition not only by virtue of the scope of his work, which allowed it to serve as an alternative to the Peripatetic heritage, but also because he was to be seen as the last major critic of Aristotle: after Descartes, such concepts as 'substantial form' or 'final cause' were widely held to have become definitively redundant.

This is not to deny the enduring relevance during the sixteenth and seventeenth centuries of competing schools of thought from Antiquity, nor to belittle the impact made by, for instance, Gassendi, Spinoza, and Hobbes on later seventeenth-century and eighteenthcentury thought, ${ }^{42}$ but it would seem that in natural philosophy Descartes delivered a decisive blow. Natural philosophy was widely held to be the crucial discipline of the two most influential competing schools of thought, namely Aristotelianism and Cartesianism, which during the middle of the seventeenth century fought the decisive battle between what was commonly referred to as the 'philosophia vetus' and the 'philosophia nova'. In response to Haakonssen's concerns over this portrayal of early modern intellectual history, it could be argued that 'after Descartes', moral and political philosophers followed the latest developments of (meta)physics, and not the other way around, and this is true both for philosophers such as Spinoza, who fit more or less within the Cartesian tradition, and for contemporaries of Descartes such as Hobbes, who steered their own course: it was only after he had turned himself into an accomplished, albeit not particularly successful, natural philosopher that Hobbes turned to politics: De cive was originally conceived as the outcome of first De corpore, and next De homine.

The gradual disintegration of the Aristotelian tradition, which during the Renaissance had remained the most powerful school of thought, had started from growing doubts concerning the Aristotelian picture of the universe. Following Copernicus's heliocentric 'systema mundi', with an increasing demand for mathematical analysis in the explanation of movement and change, crucial Aristotelian concepts such as 'natural cause' and 'substantial form' grew obsolete. Thus, Aristotle's entire conceptual vocabulary lost coherence and credibility,

42 Osler (ed.), Atoms, Pneuma and Tranquility; Jonathan I. Israel, Radical Enlightenment. Philosophy and the Making of Modernity, 1650-1750 (Oxford: Oxford University Press, 2001), and Jonathan I. Israel, Enlightenment Contested. Philosophy, Modernity, and the Emancipation of Man, 1670-1752 (Oxford: Oxford University Press, 2006); Noel Malcolm, Aspects of Hobbes (Oxford: Oxford University Press, 2004). 
and would gradually be replaced by alternative philosophies of nature not burdened by his essentially qualitative approach to natural phenomena: instead, the search was now for models allowing quantitative analysis of matter in motion. The 'form' of matter came to be reduced to the geometrical constitution of its particles.

Much as historians of science have come to distrust the jaded metaphor of a 'scientific revolution' from Copernicus to Newton, and as ingenious as they have recently been in adding social, cultural, and political dimensions to the way in which this supposed 'revolution' took place, the fact remains that after Newton natural philosophy grew into what we now call the 'natural sciences'. ${ }^{43}$ Indeed, during the eighteenth century the increasingly autonomous course it took was a major inspiration for Kant's attempt to reinvent the very nature and professional competence of philosophy as a viable enterprise alongside the natural sciences. And Kant wrote his Kritik der praktischen Vernunft (1788) only after having completed his Kritik der reinen Vernunft (1781).

By the time Gassendi, Hobbes, and Descartes, each in his own way, set out to overthrow Peripateticism, it had already been dealt a number of serious blows. As early as the mid-sixteenth century the French professor of rhetoric and eloquence Pierre de la Ramée (1515-1572), better known as Petrus Ramus, ${ }^{44}$ was mounting a massive critique of Aristotelian logic, which was taken up at several Dutch and German universities and had a considerable impact on

43 For a number of varying views: Steven Shapin, The Scientific Revolution (Chicago: University of Chicago Press, 1996); Peter Dear, Revolutionizing the Sciences. European Knowledge and Its Ambitions (Basingstoke: Palgrave, 2001); Stephen Gaukroger, The Emergence of a Scientific Culture. Science and the Shaping of Modernity, 1210-1685 (Oxford: Clarendon Press, 2006). See also H. Floris Cohen, The Scientific Revolution. A Historiographical Inquiry (Chicago: University of Chicago Press, 1994).

44 Walther J. Ong, Ramus, Method, and the Decay of Dialogue. From the Art of Discourse to the Art of Reason (Cambridge, MA: Harvard University Press, 1983); Howard Hotson, Commonplace Learning. Ramism and Its German Ramifications, 1543-1630 (Oxford: Oxford University Press, 2007).
Francis Bacon. ${ }^{45}$ Bacon was also severely critical of the Peripatetic tradition, replacing it with a Novum organon (1620) and sketching a New Atlantis (1626). To d'Alembert, Bacon's empiricist methodology and his call for turning the investigation of nature into a societal project turned him into one of the founding fathers of the Enlightenment. Although Bacon was still inspired by the vision of a 'prisca sapientia', contemporaries were in no doubt as to the innovative nature of his proposals: on account of his schemes regarding the future elucidation of nature's 'secrets', he clearly was considered to be 'modern' instead of 'ancient', and his visionary schemes on the necessity of organising a truly experimental inquiry of nature were to turn his writings into a major source of inspiration for the establishment of the Royal Society.

Next, Galileo Galilei was instrumental in demolishing Aristotelian cosmography. Once this brilliant mathematician put the newly invented telescope to use for the observation of heavenly bodies, the Peripatetic distinction between a supralunar, celestial, and sublunar, earthly realm rapidly lost credibility. Subsequently, Galileo's mathematical expertise enabled him to confirm and further refine Copernicus's heliocentrism. The reaction of the Catholic Church, which condemned his views in 1633 , became arguably the most notorious ecclesiastical intervention in the history of science during the early modern period. It would prompt Descartes to not publish his Traité $d u$ monde.

Following Ramus, Bacon, and Galileo, a series of seventeenth-century 'novatores' set out to formulate an alternative to the Aristotelian tradition still dominating the universities of Europe. In one way or another they all shared the conviction that the key to formulating a convincing alternative was to be found in mechanicism, that is, the view that the 'operations'

45 Lisa Jardine, Francis Bacon. Discovery and the Art of Discourse (Cambridge: Cambridge University Press, 1974); Perez Zagorin, Francis Bacon (Princeton, NJ: Princeton University Press, 1998); Stephen Gaukroger, Francis Bacon and the Transformation of Early Modern Philosophy (Cambridge: Cambridge University Press, 2001). 
of nature are to be analysed analogously with the way in which machines operate. ${ }^{46}$ One of the first and most coherent mechanicist as well as materialist natural philosophers, Thomas Hobbes, was to become famous for the way in which he put his world view to use in his political writings, occasioned by the chaos resulting from the English Civil War (1642-1651). His work in natural philosophy failed to attract the attention his political writings did, however, and his views on the new 'experimental philosophy' were soon superseded by Boyle's, so his impact was to remain confined mostly to the political theory and biblical criticism contained in $D e$ cive (1642) and the Leviathan (1651). ${ }^{47}$

Like Hobbes, who was a brilliant classicist, Pierre Gassendi was still deeply influenced by ancient and Renaissance philosophy. Unlike that of Hobbes, Gassendi's Epicurean natural philosophy for some time during the latter half of the seventeenth century did acquire a considerable popularity in Britain, and especially in his native France. ${ }^{48}$ By the late seventeenth century, however, Cartesian natural philosophy was beginning to replace Peripateticism even in France, much in the same way it had

46 Alan Gabbey, 'Mechanical Philosophies and Their Explanations', in Christoph Lüthy, John E. Murdoch, William R. Newman (eds.), Late Medieval and Early Modern Corpuscular Theory (Leiden and Boston: Brill, 2001), pp. 441-464; Helen Hattab, 'The Mechanical Philosophy', in The Oxford Handbook to Early Modern Philosophy, ed. by Desmond M. Clarke and Catherine Wilson (Oxford: Oxford University Press, 2011), pp. 71-95.

47 Steven Shapin and Simon Schaffer, Leviathan and the Air Pump. Hobbes, Boyle, and the Experimental Life (Princeton, NJ: Princeton University Press, 1983); Cees Leijenhorst, The Mechanisation of Aristotelianism. The Late Aristotelian Setting of Thomas Hobbes'Natural Philosophy (Leiden and Boston: Brill, 2002); Malcolm, Aspects of Hobbes. The leading authority on Hobbes's political philosophy is Quentin Skinner: Reason and Rhetoric in the Philosophy of Hobbes (Cambridge: Cambridge University Press, 1996) and Visions of Politics. Volume III: Hobbes and Civil Science (Cambridge: Cambridge University Press, 2002).

48 Olivier René Bloch, La philosophie de Gassendi. Nominalisme, matérialisme, métaphysique (The Hague: Martinus Nijhoff, 1971); Thomas M. Lennon, The Battle of the Gods and Giants. The Legacies of Descartes and Gassendi, 1655-1715 (Princeton, NJ: Princeton University Press, 1993); Antonia Lolordo, Pierre Gassendi and the Birth of Early Modern Philosophy (Cambridge: Cambridge University Press, 2007). done previously in the Netherlands, turning Cartesianism into the last major philosophical system before the advent of Newtonianism.

So the most important new system of philosophy to be launched during the early modern age was that of RenéDescartes. There are several reasons for this. First, as stated above, Descartes was the last major critic of Aristotle. Second, his conception of philosophy was itself inherently systematic, in that he famously compared it to a tree, the roots of which serve as metaphysics, its trunk as physics, and its branches as the applied sciences of medicine, mechanics, and morals. ${ }^{49}$ Thus, for a while Cartesianism appeared able to provide a credible alternative to the Corpus Aristotelicum. Third, Cartesianism was essential to the late seventeenth-century writings of both Spinoza and Bayle, while it was also deeply influential in Britain: Locke's 'Way of Ideas' was heavily indebted to Descartes, and Isaac Newton's Principia mathematica (1687) opened with a devastating critique of Descartes's physics as its point of departure. Finally, to this day Descartes has remained by far the most prominent seventeenthcentury thinker in the entire trajectory of postseventeenth-century philosophy, both in its Continental and Anglo-Saxon varieties. ${ }^{50}$

49 René Descartes, Philosophical Writings, 3 vols., transl. John Cottingham, Robert Stoothoff, Dugald Murdoch, and Anthony Kenny (Cambridge: Cambridge University Press, 1985-1991), I, p. 186.

50 As a consequence, the literature is huge. Much scholarly attention has been invested in laying bare the many ties which kept Descartes's thought connected to its mediaeval and Renaissance background: Étienne Gilson, Études sur le rôle de la pensée médiévale dans la formation du systême cartésien (Paris: Vrin, 1930); Dennis Des Chene, Physiologia. Natural Philosophy in Late Aristotelian and Cartesian Thought (Ithaca, NY: Cornell University Press, 1996). Some classical commentaries: Martial Gueroult, Descartes selon l'ordre des raisons, 2 vols. (Paris: Aubier Montaigne, 1953); Edwin Curley, Descartes Against the Skeptics (Cambridge, MA: Harvard University Press, 1978); Jean-Marie Beyssade, La philosophie première de Descartes. Le temps et la cohérence de la métaphysique (Paris: Flammarion, 1979); Jean-Luc Marion, Sur le prisme métaphysique de Descartes (Paris: Presses Universitaires de France, 1986); Daniel Garber, Descartes' Metaphysical Physics (Chicago: University of Chicago Press, 1995); Stephen Gaukroger, Descartes. An Intellectual Biography (Oxford: Oxford University Press, 1995); Desmond M. Clarke, Descartes. A Biography (Cambridge: Cambridge University Press, 2006). 
From the Discours de la méthode (1637) onwards, Descartes made every effort to present his philosophy as a new start, putting an end to the bewildering variety of old and new 'isms' penetrating contemporary scholarship. His metaphysics, put forward in the Meditationes de prima philosophia (1641), started with an attempt to overcome the 'Pyrrhonian' challenge: first, any possible occasion for doubt as to the possibility of knowledge as such had to be eliminated. Finding this 'rock bottom' in the certainty that doubt itself presupposes existence, that is: from the mind in doubt, he subsequently turned his attention to the contents of the thinking mind, which led him to an analysis of the ideas of God, mind, and matter. Having concluded that God's veracity guarantees the reliability of 'clear and distinct' ideas, Descartes ends up dividing being into the 'substances' of 'res cogitans' and 'res extensa', or mind and matter. Thus, Descartes would become the originator of metaphysical dualism: while on the one hand this posed the considerable challenge of understanding how it can be that man, consisting of a soul and a body, is nevertheless a unity of mind and matter, it also enabled him to create a physics based on the notion that the material universe holds no causal relation to mind and that it is essentially extended, that is, threedimensional. Descartes's physics, a first sketch of which he refrained from publishing after Galileo's condemnation in 1633, was finally presented in the Principia philosophiae (1644). It is reductionist in its ambition to reduce the sensory qualities of material objects to the elementary particles which make up these objects, and which are really known only by their geometrical properties. It is mechanistic on account of the model in which Descartes presented his attempts to produce his quantitative analyses of matter in motion: according to Descartes, the 'operations' of Nature were to be compared to the workings of an immense machine.

Descartes's books provoked a huge number of sometimes vitriolic reactions, first in the Netherlands, where he had spent most of his working life, and subsequently in Germany and France; but he was soon to acquire a considerable following both among academics and outside the universities. ${ }^{51}$ Several major philosophers in their own right took Cartesianism as their point of departure, for both Benedictus de Spinoza and Pierre Bayle are probably best understood from a Cartesian perspective. Spinoza, a Dutch Jew expelled from the Portuguese synagogue of Amsterdam, is now considered to be the main source of inspiration for the Radical Enlightenment stretching from the late seventeenth-century Dutch Republic to the heart of the eighteenth-century 'siècle des lumières'. ${ }^{52}$ While his Ethica (1677) employs a Cartesian terminology, it rejects Descartes's dualism, replacing it with the notion of a single, all-encompassing 'Deus sive Natura'; Spinoza's Tractatus theologico-politicus (1670) is often read in conjunction with Hobbes's political philosophy.

Pierre Bayle, also known as le philosophe de Rotterdam', first made a name for himself with his Commentaire philosophique (1687), a brilliant plea in favour of religious toleration. His main claim to fame, however, was the Dictionnaire historique et critique (1697), which was to

51 On the Dutch reception, see Theo Verbeek, Descartes and the Dutch. Early Reactions to Cartesian Philosophy, 1637-1650 (Carbondale: Southern Illinois University Press, 1992); J. A. van Ruler, The Crisis of Causality. Voetius and Descartes on God, Nature, and Change (Leiden: Brill, 1995); Wiep van Bunge, From Stevin to Spinoza. An Essay on Philosophy in the Seventeenth-Century Dutch Republic (Leiden and Boston: Brill, 2001). For France, see most recently Tad M. Schmaltz, Radical Cartesianism. The French Reception of Descartes (Cambridge: Cambridge University Press, 2002), and Tad M. Schmaltz (ed.), Receptions of Descartes. Cartesianism and Anti-Cartesianism in Early Modern Europe (London: Routledge, 2005); Steven Nadler, Occasionalism. Causation among the Cartesians (Oxford: Oxford University Press, 2011). On the most important German Cartesian, see Theo Verbeek (ed.), Johannes Clauberg (1622-1665) and Cartesian Philosophy in the Seventeenth Century (Dordrecht: Kluwer, 1999).

52 Martial Gueroult, Spinoza I. Dieu(Hildesheim: Olms, 1968); Martial Gueroult, Spinoza II. L'Âme (Hildesheim: Olms, 1974); Alexandre Matheron, Individu et communauté chez Spinoza (Paris: Minuit, 1969); Edwin Curley, Spinoza's Metaphysics. An Essay in Interpretation (Cambridge, MA:Harvard University Press, 1969);Jonathan Bennett, A Study of Spinoza's Ethics (Cambridge: Cambridge University Press, 1984); Pierre-François Moreau, Spinoza. L'expérience et l'éternité (Paris: Presses Universitaires de France, 1994); Steven Nadler, Spinoza. A Life (Cambridge: Cambridge University Press, 1999); Israel, Radical Enlightenment; Michael Della Rocca, Spinoza (London and New York: Routledge, 2008). 
become a hugely influential book of reference during the Enlightenment, although Bayle's own philosophical stance continues to vex the specialists to this day: he has been called a Cartesian, a sceptic, a covert Spinozist, and much more. ${ }^{53}$ But as has been noted, it is doubtful whether Bayle should even be mentioned in a Neo-Latin encyclopaedia. Although his Latin left little to be desired, he published nearly exclusively in the vernacular, as did his contemporary John Locke. By the late seventeenth century, Latin was rapidly becoming irrelevant to philosophical discourse. Leibniz, the author of a final, grandiose attempt to combine the best of both the 'old' and the 'new' philosophies, still used Latin regularly, but both his response to Locke, The Nouveaux Essais (1704), and to Bayle, Essais de théodicée (1711), were composed in French. 54

\section{FURTHER READING}

Catana, Leo, The Historiographical Concept 'System of Philosophy'. Its Origin, Nature, Influence and Legitimacy (Leiden and Boston: Brill, 2008).

Copenhaver, Brian P., and Charles B. Schmitt, Renaissance Philosophy (Oxford: Oxford University Press, 1993).

Garber, Daniel, and Michael Ayers (eds.), The Cambridge History of Seventeenth-Century Philosophy, 2 vols. (Cambridge: Cambridge University Press, 1998).

Gaukroger, Stephen, The Emergence of a Scientific Culture. Science and the Shaping of Modernity, 1210-1685 (Oxford: Clarendon Press, 2006).

Haakonssen, Knud, Natural Law and Moral Philosophy. From Grotius to the Scottish Enlightenment (Cambridge: Cambridge University Press, 2006).

Hankins, James (ed.), The Cambridge Companion to Renaissance Philosophy (Cambridge: Cambridge University Press, 2007).

Israel, Jonathan I., Radical Enlightenment. Philosophy and the Making of Modernity, 1650-1750 (Oxford: Oxford University Press, 2001).

Nadler, Steven (ed.), A Companion to Early Modern Philosophy (Oxford: Blackwell, 2002).

Popkin, Richard H., The History of Scepticism from Savonarola to Bayle (Oxford: Oxford University Press, 2003).

Schmitt, Charles B., and Quentin Skinner (eds.), The Cambridge History of Renaissance Philosophy (Cambridge: Cambridge University Press, 1988).

53 Élisabeth Labrousse, Pierre Bayle, 2 vols. (The Hague: Martinus Nijhoff, 1963-1964); Gianluca Mori, Bayle philosophe (Paris: Honoré Champion, 1999); Thomas M. Lennon, Reading Bayle (Toronto: University of Toronto Press, 1999); Antony McKenna and Gianni Paganini (eds.), Pierre Bayle dans la République des Lettres. Philosophie, religion, critique (Paris: Honoré Champion, 2004); Hubert Bost, Pierre Bayle (Paris: Fayard, 2006).

54 Donald Rutherford, Leibniz and the Rational Order of Nature (Cambridge: Cambridge University Press, 1995); Christa Mercer, Leibniz'Metaphysics. Its Origins and Development (Cambridge: Cambridge University Press, 2001); Maria Rosa Antognazza, Leibniz. An Intellectual Biography (Cambridge: Cambridge University Press, 2009). 
